\title{
EVALUASI MUTU KOPI ROBUSTA DI KECAMATAN KARE KABUPATEN MADIUN JAWA TIMUR
}

\section{[Quality Evaluation of Robusta Coffee in Kecamatan Kare, Madiun District, East Java]}

\author{
Choiroel Anam ${ }^{\left.1,2,3^{*}\right)}$, Eny Muzayana ${ }^{1)}$, Rohmat Priya Atmaja ${ }^{1)}$, Didik Purnomo ${ }^{1)}$ \\ 1)Program Studi DII Teknologi Pengolahan Hasil Pertanian \\ Pendidikan Di Luar Domisili (PDD) Universitas Sebelas Maret. \\ 2) Program Studi Ilmu Teknologi Pangan Fakultas Pertanian UNS. \\ 3) Halal Research Center and Service UNS \\ * Email : choiroelanam@staff.uns.ac,id
}

Diterima 10 Oktober 2020 / Disetujui 21 Januari 2021

\begin{abstract}
Coffee is a leading commodity in Madiun Regency, East Java, the area of coffee plantations in 2018 is $1,432 \mathrm{Ha}$ with an average productivity of $769.63 \mathrm{~kg} / \mathrm{ha} / \mathrm{year}$. This study aims to provide information on the physical, chemical, and microbiological quality characteristics of rice coffee, roasted coffee beans and evaluate the primary processing procedures for Mugi Lestari Farmer Group's coffee in Kare Village, Kare District, Madiun Regency. Evaluation of the quality of coffee rice is based on general and specific quality equirements according to SNI 01-2907: 2008. Organoleptic and chemical analysis of rice coffee and roasted coffee beans was carried out to see the state (smell, taste), moisture content, ash content, ash alkalinity, caffeine content, sugar content (reducing), insoluble solids, metal contaminants ( $\mathrm{Pb}$ and $\mathrm{Cu}$ ). Assessment of the physical quality of coffee beans shows that the robusta rice coffee produced at Poktan Mugi Lestari has quality according to SNI 01-2907-2008, especially for the parameters of the presence of insects, moisture content, impurities, and no found odor/mold. Physical quality of roasted coffee beans from Poktan Mugi Lestari when compared to SNI standards has a normal condition, both in terms of smell, taste, and appearance. Chemical parameters of roasted coffee bean samples are also in accordance with the general requirements for roasted coffee (SNI 012983-1992). The number of bacteria and molds is less than the maximum limit set. Assessment of physical, chemical, and microbiological quality of packaged coffee powder has a value in accordance with the SNI quality requirements, both for caffeine content, the amount of mold, and bacteria (ALT value), and water content. The primary coffee processing process at Poktan Mugi Lestari has been able to produce rice coffee in accordance with SNI requirements.
\end{abstract}

Keywords: coffee, robusta, quality, kare madiun

\begin{abstract}
ABSTRAK
Kopi merupakan komoditas unggulan di Kabupaten madiun Jawa Timur, Luas areal perkebunan kopi tahun 2018 di Kabupaten Madiun 1.432 Ha dengan produktivitas rata rata 769,63 kg/ha/tahun. Penelitian ini bertujuan memberikan informasi karakteristik mutu fisik, kimiawi, dan mikrobiologis dari kopi beras, kopi biji sangrai dan mengevaluasi prosedur pengolahan primer kopi Kelompok Tani Mugi Lestari di desa Kare, Kecamatan Kare, Kab Madiun, agar dihasilkan produk dengan mutu yang baik. Evaluasi mutu kopi beras didasarkan pada syarat mutu umum dan khusus sesuai SNI 01-2907:2008. Analisa organoleptik dan kimiawi kopi beras dan kopi biji sangrai dilakukan untuk melihat keadaan (bau, rasa), kadar air, kadar abu, kealkalian abu, kadar kafein, kadar gula (pereduksi), padatan tak larut dalam air, cemaran logam ( $\mathrm{Pb}$ dan $\mathrm{Cu}$ ). Penilaian mutu fisik biji kopi diketahui bahwa kopi beras robusta yang dihasilkan di Poktan Mugi Lestari memiliki mutu sesuai dengan SNI 01-2907-2008, khususnya untuk parameter keberadaan serangga, nilai kadar air, pengotor, dan tidak ditemukannya bau busuk/kapang. Keadaan mutu fisik biji kopi sangrai dari Poktan Mugi Lestari jika dibandingan dengan SNI 01-2983-1992 memiliki keadaan yang normal, baik dalam hal bau, rasa, dan penampakan. Parameter kimiawi biji kopi sangrai dalam penelitian juga sesuai dengan syarat umum kopi sangrai (SNI 01-2983-1992). Jumlah bakteri dan kapang kurang dari batas maksimum yang ditetapkan. Penilaian mutu fisik, kimiawi, dan mikrobiologis bubuk kopi yang dikemas memiliki nilai sesuai dengan persyaratan mutu SNI, baik untuk kadar kafein, jumlah kapang, dan bakteri (nilai ALT), dan kadar air. Proses pengolahan primer kopi di Poktan Mugi Lestari sudah mampu menghasilkan kopi beras yang sesuai dengan persyaratan SNI.
\end{abstract}

Kata kunci: Kopi, Robusta, Mutu, Kare Madiun 
Versi Online:

http://www.profood. unram.ac.id/index.php/profood e-ISSN: 2443-3446

\section{PENDAHULUAN}

Kabupaten Madiun dikenal sebagai penghasil kopi. Menurut Badan Pusat Statistik (BPS) Provinsi Jawa timur, luas areal perkebunan kopi di kabupaten Madiun adalah $1.432 \mathrm{Ha}$. Salah satu perkebunan kopi berada di wilayah lereng gunung Wilis terutama di desa Kare yang berada di kecamatan Kare (Anonim, 2018 ${ }^{\mathrm{a}}$, Anonim, 2018 ${ }^{\mathrm{b}}$ ). Perkebunan kopi di desa Kare dikelola oleh Kelompok Tani (Poktan). Area budidaya kopi yang berada di pengelolaan kelompok tani ini seluas $38 \mathrm{Ha}$ dengan produksi rata-rata 20 ton gelondong kopi basah. Karena faktor ketinggian tempat, maka jenis kopi yang dibudidayakan di Kare adalah robusta (Anonim, 2016). Potensi kebun kopi di Kare dapat dijadikan salah satu area Ekowisata karena alamnya yang indah sekaligus sebagai pemasaran yang sangat menjanjikan, dengan engembangkan lahan pekebunan (Yuhana \& Nurhikmawati, 2017)

Menurut Direktorat Jenderal Pertanian (Anonim, 2017) permasalahan yang sering terjadi pada komoditas kopi antara lain produktivitas tanaman yang rendah, terbatasnya ketersediaan benih, dan mutu kopi yang dihasilkan rendah. Dari ketiga permasalahan tersebut, permasalahan utama dari Poktan di Kare adalah tidak adanya keseragaman produk kopi yang dihasilkan sehingga mutu produk kopi bervariasi. Di sisi lain masalah pokok persaingan pada perdagangan global menunjukkan fluktuasi nilai ekspor sangat ditentukan pada konsep keunggulan kompetitif dan keunggulan komparatif (Baroh dkk, 2014). (Setyani dkk, 2018) menyampaikan bahwa jika ditemukaan cacat pada biji kopi yang terdiri dari biji pecah, biji coklat, biji hitam kemudian diikuti biji berlubang dan yang utuh hanya $70 \%$ mutu kopi sudah tidak sesuai dengan SNI 01-29072008. Hal ini menandakan perlunya penerapan prosedur operasional yang baik dan standar untuk meningkatkan mutu kopi di tingkat Industri kecil dan menengah (IKM)

Profil mutu kopi yang dihasilkan di Kare belum diketahui sehingga tidak dapat dibandingkan antara mutu kopi di Kare dengan Standar Nasional Indonesia (SNI). Selama ini produk kopi yang dihasilkan di Kare memiliki mutu yang beragam baik pada kopi beras, kopi biji sangrai, atau kopi bubuk. Informasi awal tentang mutu kopi diperlukan sebagai bahan pembanding dalam menentukan mutu kopi serta sebagai bahan evaluasi selama proses pengolahan.

\section{BAHAN DAN METODE}

Penelitian dilaksanakan di Laboratorium Teknologi Hasil Pertanian PS DII THP K. Kab. Madiun PDD UNS, Kelompok Tani Mugi Lestari, dan di PT. Saraswanti Indo Genetech. Proses pembuatan kopi beras dan penyangraian dilakukan di Kelompok Tani Mugi Lestari kecamatan Kare Kabupaten Madiun. Pemeriksaaan karakteristik mutu fisik, (serangga, kadar air, kotoran, nilai cacat. biji berbau busuk) sifat kimia (kafein, tembaga $/ \mathrm{Cu}$, Timbal $/ \mathrm{Pb}$ dan Mikrobiologis (bakteri/kapang, ALT), serta organoleptik ( bau, penampkan, rasa) dilakukan di PT. Saraswanti Indo Genetech. Penelitian dilakukan selama bulan Oktober hingga November 2019.

Penelitian dilaksanakan secara deskriptif eksploratif. Data hasil analisa karakteristik mutu fisik, kimiawi, dan mikrobiologis pada kopi beras, dan biji kopi sangrai dipaparkan secara rinci. Data tersebut selanjutnya dibandingkan dengan syarat umum mutu kopi beras dan kopi biji sangrai yang ada di Standar Nasional Indonesia (SNI) masing-masing dengan Nomor SNI 29072008 dan SNI 01-2891-1992 untuk dikaitkan dengan pengolahan kopi yang dilakukan oleh Kelompok Tani.

Penelitian diawali dengan pemeriksaan syarat mutu kopi beras dengan kriteria serangga hidup, biji berbau busuk dan atau berbau kapang, kadar air, kadar kotoran, serta nilai cacat (Metode SNI 2907-2008). Pemeriksaan kedua dilakukan pada biji kopi sangrai yang melihat parameter kadar kafein, tembaga, $\mathrm{Pb}, \mathrm{ALT}$, kapang, padatan tidak 
larut air, kealkalian abu, kadar abu, kadar air, bau, penampakan, rasa, dan gula pereduksi.

$$
\text { Variabel penelitian meliputi }
$$

pengamatan langsung terhadap karakteristik mutu fisik, kimia, dan mikrobiologis baik pada kopi beras dan biji kopi sangrai. Parameter yang diamati meliputi analisa karakteristik mutu fisik, kimia, dan mikrobiologis dari kopi beras antara lain melihat parameter keberadaan serangga, kadar air, persentase kotoran, nilai cacat, dan bau dari biji/kopi beras. Sedangkan karakteristik mutu fisik, kimia, dan mikrobiologis dari biji kopi sangrai antara lain mengukur kadar kafein, kandungan logam (Tembaga dan Timbal), Angka Lempeng Total (ALT), jumlah kapang, persentase padatan tidak larut air, kealkalian abu, kadar abu, kadar air, dan keadaan bau dari biji kopi sangrai. ( Metode SNI 2907-2008 dan SNI 01-2891-1992).

\section{HASIL DAN PEMBAHASAN}

Uji fisik dalam menilai mutu biji kopi merupakan suatu sistem yang digunakan untuk menilai kualitas dari biji kopi berdasarkan fisiknya, baik menggunakan alat bantu atau menggunakan indra manusia sesuai dengan standar yang berlaku (Gayo Cuppers Team, 2017). Syarat mutu fisik biji kopi secara umum menurut SNI 01-29072008 meliputi ada-tidaknya serangga hidup, biji berbau busuk dan atau berbau kapang, kadar air, dan kadar kotoran. Hasil uji mutu fisik biji kopi dalam penelitian dapat dilihat pada Tabel 1.

Dari syarat mutu umum dalam penilaian mutu fisik biji kopi diketahui bahwa kopi beras robusta yang dihasilkan di Poktan Mugi Lestari memiliki mutu sesuai dengan SNI 01-2907-2008, khususnya untuk parameter keberadaan serangga, nilai kadar air, pengotor, dan tidak ditemukannya bau busuk/kapang. Nilai kadar air serta persentase kopi beras dari Poktan Mugi Lestari lebih kecil jika dibandingkan dengan batas maksimum yang dipersyaratkan dalam dalam SNI 012907-2008, yaitu 12,5\% (untuk kadar air) dan $0,5 \%$ (untuk kotoran). Hal tersebut menandakan jika proses pengeringan, pengemasan, dan penyimpanan kopi beras di Poktan Mugi Lestari sudah berlangsung baik.

Dari Tabel 1 diketahui nilai cacat pada biji kopi beras memiliki nilai 26,50. Nilai tersebut jika dibandingkan dengan persyaratan mutu khusus tentang penggolongan mutu kopi robusta dan arabika dalam SNI 01-2907-2008 dapat dikelompokkan ke dalam kelompok Mutu 3 (dengan jumlah nilai cacat 26-44). Kopi beras yang diproduksi di Poktan Mugi Lestari selama ini belum dilakukan penggolongan berdasarkan mutu biji. Dari hasil penelitian tersebut sebaiknya dilakukan penggolongan mutu khususnya pada kopi beras yang dihasilkan agar ada perbedaan harga jual serta peningkatan mutu pada bubuk kopi (olahan lanjutan) yang produksi.

Kopi biji sangrai merupakan olahan lanjutan dari kopi beras yang juga diproduksi oleh Poktan Mugi Lestari. Mutu biji kopi sangrai juga ditentukan oleh mutu biji pada kopi beras. Hasil analisa karakteristik mutu fisik, kimiawi, dan mikrobiologis biji kopi sangrai dapat dilihat pada Tabel 2.

Tabel 1. Hasil Analisa Karakteritik Mutu Fisik Kopi Beras dari Poktan Mugi Lestari

\begin{tabular}{llll}
\hline \multicolumn{1}{c}{ Parameter } & \multicolumn{1}{c}{ Unit } & \multicolumn{1}{c}{ Hasil } & \multicolumn{1}{c}{ Persyaratan (SNI)* } \\
\hline 1. Serangga & - & Negative & Tida ada \\
2. Kadar Air & $\%$ & 8,38 & Maksimum 12,5 \\
3. Kotoran & $\%$ & 0 & Maks. 0,5 \\
4. Nilai Cacat & - & 26,50 & $11-225$ \\
5. Biji berbau busuk/kapang & - & Tidak ada & Tidak ada \\
\hline
\end{tabular}

Keterangan: SNI 2907-2008 
Tabel 2. Hasil Analisa Karakteritik Mutu Fisik, Kimiawi, dan Mikrobiologis Kopi Biji Sangrai dari Poktan Mugi Lestari

\begin{tabular}{|c|c|c|c|}
\hline Parameter & Unit & Hasil & Persyaratan (SNI)* \\
\hline 1. Kafein & $\mathrm{mg} / \mathrm{kg}$ & 24785,65 & $2-8 \%$ \\
\hline 2. Tembaga (Cu) & $\mathrm{mg} / \mathrm{kg}$ & 16,13 & maksimum 30 \\
\hline 3. Timbal (Pb) & $\mathrm{mg} / \mathrm{kg}$ & $\begin{array}{l}\text { Tidak } \\
\text { terdeteksi }\end{array}$ & maksimum 30 \\
\hline 4. ALT & colony/g & $<10$ & maksimum 300 \\
\hline 5. Kapang & colony $/ g$ & $<10$ & (tidak disebutkan di SNI) \\
\hline 6. Padatan tidak larut air & $\%$ & 75,99 & (tidak disebutkan di SNI) \\
\hline 7. Kealkalian abu & $\mathrm{ml} \mathrm{NaOH} 1 \mathrm{~N} / 100 \mathrm{~g}$ & 52,92 & $80-140$ \\
\hline 8. Kadar abu & $\%$ & 5,20 & $7-14$ \\
\hline 9. Kadar air & $\%$ & 1,30 & Maks. 4 \\
\hline 10. Bau & - & Normal & Normal \\
\hline 11. Penampakan & - & Normal & Normal \\
\hline 12. Rasa & - & Pahit & Normal \\
\hline 13. Gula pereduksi & $\%$ & $\begin{array}{l}\text { Tidak } \\
\text { terdeteksi }\end{array}$ & - \\
\hline
\end{tabular}

keterangan*: SNI 01-2891-1992

Penelitian parameter mutu fisik biji kopi sangrai yang diproduksi oleh Kelompok Tani/Poktan Mugi Lestari meliputi bau, penampakan, dan rasa; parameter kimiawi melihat kandungan gula pereduksi, kadar air, kadar abu, kealkalian abu, padatan tidak larut air, cemaran logam berat (kadar timbal dan tembaga), kadar kafein; dan parameter mikrobiologis yang melihat jumlah kapang dan jumlah bakteri berdasarkan analisa angka lempeng total (ALT). Dari hasil analisa menunjukkan bahwa masing-masing parameter memiliki nilai yang sesuai dengan syarat umum kopi sangrai menurut SNI 012983-1992.

Keadaan mutu fisik biji kopi sangrai dari Poktan Mugi Lestari jika dibandingan dengan SNI 01-2983-1992 memiliki keadaan yang normal, baik dalam hal bau, rasa, dan penampakan. Hal tersebut menunjukkan bahwa kopi biji sangrai yang diproduksi di Poktan Mugi Lestari sesuai dengan persyaratan umum kopi sangrai. Keseuaian dengan SNI juga menunjukkan bahwa proses penyangraian, pengemasan, dan penyimpanan kopi biji sangrai sudah dilakukan dengan baik. Pengemasan kopi biji sangrai di Poktan Mugi Lestari menggunakan plastik polipropilen 0,5 yang mampu menjaga biji dari kondisi yang lembab serta mampu menjaga dari cemaran biologis/mikrobiologis yang mempengaruhi mutu fisik kopi biji sangrai.

Dalam penelitian, kadar air kopi biji sangrai yang terukur memiliki nilai yang lebih kecil jika dibandingkan dengan syarat umum kopi sangrai (SNI 01-2983-1992). Nilai kadar air yang terdapat pada suatu produk dipengaruhi oleh bahan baku, kemasan, dan kondisi tempat menyimpan. Nilai kadar air juga menjadi faktor penentu kecepatan kerusakan baik secara kimiawi ataupun secara mikrobiologis. Kadar air yang tinggi dapat memicu reaksi oksidasi serta mempercepat proses hidrolisis. Kadar air yang tinggi juga memicu pertumbuhan kapang (Yani, 2008).

Parameter kimiawi biji kopi sangrai dalam penelitian juga sesuai dengan syarat umum kopi sangrai (SNI 01-2983-1992). Kadar kafein dalam kopi biji sangrai dari Poktan Mugi Lestari memiliki kadar 2,4\%, nilai tersebut masih dalam rentang kadar kafein (28) dalam SNI. Kafein merupakan senyawa alkaloid yang terkandung dalam biji kopi. Kafein memberikan citarasa yang pahit pada saat kopi diseduh. Kadar kafein dalam kopi dipengaruhi oleh jenis kopi, lingkungan, dan pengolahan pasca panen (Farida, A. dkk).

Selain kadar kafein juga dilihat kandungan logam berat, khususnya tembaga (Cu) dan timbal $(\mathrm{Pb})$. Kriteria syarat umum kadar logam berat dalam SNI 01-2983-1992 
adalah tidak boleh lebih dari $30 \mathrm{mg} / \mathrm{kg}$. Pada hasil analisa jumlah kandungan tembaga adalah $16,13 \mathrm{mg} / \mathrm{kg}$ untuk tembaga $(\mathrm{Cu})$ dan tidak ditemukan kandungan timbal $(\mathrm{Pb})$. Bahaya logam berat termasuk cemaran kimiawi yang bersumber dari polutan yang terdapat dalam asap kendaraan bermotor, cat, dan penggunaan pestisida. Kandungan logam berat yang rendah dan bahkan tidak terdeteksi kandungan timbal $(\mathrm{Pb})$ menandakan bahwa dalam pengolahan kobi biji sangrai jauh dari penyebab kontaminasi oleh logam berat. Dalam kopi logam berat dapat berasal dari asap kendaraan bemotor, residu pestisida, dan limbah industri (Handayani, 2007).

Jumlah padatan tidak larut dalam air menandakan jumlah zat yang termasuk dalam kelompok polisakarida tidak larut air atau berasal dari kelompok lipid. Persyaratan umum dalam SNI 01-2983-1992 nilai batas maksimum untuk padatan tidak larut air memiliki nilai $0,25 \%$. Nilai tersebut lebih kecil jika dibandingkan dengan hasil analisa yaitu sebesar 75,99\%. Nilai padatan tidak larut air yang tinggi kemungkinan berasal dari kandungan karbohidrat tidak larut air dan kandungan lipid yang besar. Identifikasi senyawa yang termasuk dalam kelompok padatan tidak larut diperlukan agar diketahui jenis senyawa yang dapat memberikan ciri atau kekhasan biji kopi yang ada di daerah Kare (Putri, 2017).

Abu merupakan residu anorganik dari pembakaran bahan organik. Isi dan komposisinya tergantung dari sifat bahan yang dibakar dan metode pengabuannya. Kadar abu bahan berkaitan erat dengan kandungan mineral. Mineral yang terdapat dalam suatu bahan dapat berupa garam organik dan garam anorganik. Menurut SNI 01-2983-1992 kadar abu biji kopi sangrai dari Poktan Mugi Lestari memiliki nilai yang lebih kecil, yaitu 5,2. Abu yang dihasilkan dari pengabuan kopi bersifat alkalis, terdiri dari magnesium, kalium, dan natrium. Tingginya nilai kealkalian abu menunjukkan tingginya komponen mineral dalam biji kopi (Hartari, 2016).
Kadar air pada biji kopi sangrai memiliki nilai $1,3 \%$, nilai tersebut lebih kecil jika dibandingkan dengan persyaratan umum dalam SNI 01-2983-1992 nilai batas maksimum untuk kadar air memiliki nilai maksimum $4 \%$. Dalam analisis tidak ditemukan gula pereduksi, hal ini menunjukkan bahwa proses penyangraian kopi tidak sampai menyebabkan karamelisasi gula yang terdapat dalam biji kopi (Fadri dkk, 2019). Kadar air pada kopi selain oleh proses penyangraian, antara lain juga dipengaruhi oleh lamanya fermentasi akibat terjadinya perombakan glukosa yang besar saat fermentasi sehingga kadar air pada biji kopi yang dihasilkan lebih rendah dengan perlakuan fermentasi semakin lama. Hasil ini sesuai dengan (Sivetz, 1985) yang menyampaikan kadar air kopi bubuk akan semakin rendah ketika konsentrasi Saccharomyces cerevisiae semakin tinggi karena jumlah air bebas yang terdapat pada lendir kopi semakin banyak digunakan oleh mikroorganisme untuk berkembang biak.

Dari hasil analisa jumlah bakteri berdasarkan penghitungan angka lempeng total (ALT) diketahui jumlah bakteri pada biji kopi sangrai lebih rendah dari nilai bakteri yang dipersyaratkan umum dalam SNI 012983-1992. Rendahnya jumlah bakteri dan kapang pada biji kopi sangrai berkaitan dengan kadar air yang kecil. Kadar air berkaitan dengan pertumbuhan bakteri/kapang, semakin tinggi kadar air maka mikroorganisme mudah tumbuh dan mempengaruhi sifat fisik dan kimiawi kopi (Yani, 2008).

Berdasarkan syarat umum kopi sangrai menurut SNI 01-2983-1992 keadaan fisik kopi sangrai dari Poktan Mugi Lestari dinilai normal, baik keadaan bau dan rasa dari kopi robusta sangrai tidak ditemukan hasil yang menyimpang. Sifat kimiawi yang melihat kadar air, kadar abu, kealkalian abu, kadar kafein, cemaran logam berat (baik timbal dan tembaga) serta jumlah padatan tidak larut air dinilai normal.

Penyangraian merupakan tahap penting dalam pengembangan citarasa dan 
Versi Online:

http://www.profood. unram.ac.id/index.php/profood e-ISSN: 2443-3446

aroma biji kopi. Perbedaan tingkat sangrai akan menghasilkan citarasa yang berbeda pula. Selama penyangraian, biji kopi mengalami perubahan fisik dan kimia seperti kadar air, warna, volume, kekerasan dan komponen volatil. Proses penyangraian adalah proses pembentukan rasa dan aroma pada biji kopi. Apabila biji kopi memiliki keseragaman dalam ukuran, specific grafity, tekstur, kadar air dan struktur kimia, maka proses penyangraian akan relatif lebih mudah untuk dikendalikan. Kenyataannya biji kopi memiliki perbedaan yang sangat besar, sehingga proses penyangraian merupakan seni dan memerlukan ketrampilan dan pengalaman sebagaimana permintaan konsumen (Joko dkk, 2009).

\section{KESIMPULAN}

Penilaian mutu fisik biji kopi diketahui bahwa kopi beras robusta yang dihasilkan di Poktan Mugi Lestari memiliki mutu sesuai dengan SNI 01-2907-2008, khususnya untuk parameter keberadaan serangga, nilai kadar air, pengotor, dan tidak ditemukannya bau busuk/kapang. Keadaan mutu fisik biji kopi sangrai dari Poktan Mugi Lestari jika dibandingan dengan SNI 01-29831992 memiliki keadaan yang normal, baik dalam hal bau, rasa, dan penampakan. Parameter kimiawi biji kopi sangrai dalam penelitian juga sesuai dengan syarat umum kopi sangrai (SNI 01-2983-1992) serta jumlah bakteri dan kapang kurang dari batas maksimum yang ditetapkan.

\section{UCAPAN TERIMAKASIH}

Terima kasih kami sampikan kepada LPPM Universitas Sebelas Maret dan Pemerintah Kabupaten Madiun yang telah memberikan kesempatan dalam Penelitian Kerjasama.

\section{DAFTAR PUSTAKA}

Anonim. 2016. Badan Ketahanan Pangan (BKP) Pemerintah Daerah Kabupaten Madiun. Kopi Kare Enak Dewe.
Pro Food (Jurnal IImu dan Teknologi Pangan) Vol 6 No. 2 November 2020 ISSN: 2443-1095

bkp.madiunkab.go.id.

https://www.google.com

Anonim. 2017. Direktorat Jenderal Pertanian. Pedoman Teknis Budidaya Kopi yang Baik (Good Agricultural Practices). Kementerian Pertanian Jakarta. ditjenbun.pertanian.go.id. https://www.google.com.

Anonim. 2018 ${ }^{\mathrm{a}}$ Badan Pusat Statistik (BPS) Provinsi Jawa Timur, Luas Areal Tanaman Perkebunan Kopi di Jawa Timur 2006-2017 (Ha). https://jatim.bps.go.id

Anonim. 2018 . Dinas Perkebunan (Disbun) Provinsi Jawa Timur, Profil Perkebunan: Kandangan Kabupaten Madiun. Disbun.jatimprov.go.id. https://www.google.com

Baroh, I., Hanani, N., Setiawan, B., \& Koestiono, D. 2014. Indonesian Coffee Competitiveness in the International Market: Review from the Demand Side. In International Journal of Agriculture Innovations and Research, 3(2): 605609.

Fadri, R. A., Sayuti, K., Nazir, N., \& Suliansyah, I. 2019. Review Proses Penyangraian Kopi Dan Terbentuknya Akrilamida Yang Berhubungan Dengan Kesehatan. Journal of Applied Agricultural Science and Technology. https://doi.org/10.32530/jaast.v3i1.82, 3(1): 130 - 145.

Farida, A., Ristanti, E., Cahyo K, A. (2013). Penurunan Kadar Kafein dan Asam Total Pada Biji Kopi Robusta Menggunakan Teknologi Fermentasi Anaerob Fakultatif Dengan Mikroba Nopkor MZ Dengan Mikroba Nopkor MZ-15. Jurnal Teknologi Kimia Dan Industri, 2(3): 70 - 75.

Gayo Cuppers Team. 2017. Standart Umum Pengujian Mutu pada Bijin Kopi. https://www.tpsaproject.com.

Handayani, R. (2007). Analisis Cemaran Logam (Pb, Cu, Sn, Zn) Pada Kopi Bubuk Laporan Praktik Kerja Lapangan. In F MIPA Universitas Indonesia.

Hartari, WR. 2016. Survei Mutu (Kadar Abu, Padatan Tidak Larut) dan Keamanan Produk Gula Merah (Kandungan Boraks) di Pasar Kota Bandar Lampung. 
Skripsi-Jurusan Teknologi Hasil

Pertanian Fakultas Pertanian

Universitas Lampung.

https://www.digilib.unila.ac.id.

Joko, N., Lumbanbatu, J., \& Sri, R. 2009.

Pengaruh Suhu dan Lama

Penyangraian Terhadap Sifat FisikMekanis Biji Kopi Robusta. Seminar Nasional Dan Gelar Teknologi PERTETA.

Putri NE. 2017. Analisis Total Padatan Tak Larut Air dan Sifat Organoleptik Madu Sawo Achras zapota L.). Jagros Vol. 2 No. 1. https://www.scholar.google.com

Setyani, S., Subeki, S., \& Grace, H. A. 2018. Evaluasi Nilai Cacat Dan Cita Rasa Kopi Robusta (Coffea Canephora L.) Yang Diproduksi Ikm Kopi Di Kabupaten Tanggamus [Evaluation of Defect Value and Flavour Robusta Coffee (Coffea canephora L.) Produced by Small and Medium Industri Sector of Coffee in Tanggamus District]. Jurnal Teknologi \& Industri Hasil Pertanian. https://doi.org/10.23960/jtihp, 23(2): 103-114.

Sivetz, M. 1985. How Acidity Affects Coffee Flavour. Di dalam Botany, Biochemistry and Production of Beans and Beverage. The AVI Publishing Company, Inc., Westport, Connecticut.

Yani A. 2008. Infeksi Cendawan pada Biji Kopi selama Proses Pengolahan Primer (Studi Kasus di Propinsi Bengkulu). Jurnal Akta Agrosia Vol.11 No.1. https://ejurnal.litbang.pertanian.go.id

Yuhana, W. L., \& Nurhikmawati, A. R. 2017. Pemberdayaan Masyarakat Dusun Suweru Dalam Pemasaran Produk Kopi Lokal Melalui Strategi Marketing Mix. Prosiding Seminar Nasional Hasil Pengabdian Kepada Masyarakat Tahun 2017, 52-57. 